\title{
Seasonal variability in nutrient regeneration by mussel Mytilus edulis rope culture in oligotrophic systems
}

\author{
Henrice M. Jansen ${ }^{1,2,3, *}$, Øivind Strand ${ }^{1}$, Tore Strohmeier ${ }^{1}$, Cathinka Krogness ${ }^{1}$, \\ Marc Verdegem ${ }^{3}$, Aad Smaal ${ }^{2,3}$ \\ ${ }^{1}$ Institute of Marine Research, Nordnesgaten 50, 5817 Bergen, Norway \\ ${ }^{2}$ Wageningen IMARES-Institute for Marine Resources and Ecosystem Studies, Korringaweg 5, 4401 NT Yerseke, \\ The Netherlands \\ ${ }^{3}$ Department of Aquaculture and Fisheries, Wageningen University, Marijkeweg 40, 6709 PG Wageningen, The Netherlands
}

\begin{abstract}
Blue mussel Mytilus edulis cultures contribute to nutrient cycling in coastal ecosystems. Mussel populations filter particulate nutrients from the water column and inorganic nutrients are regenerated by excretion of metabolic wastes and decomposition of (pseudo-)faeces. The objective of this study was to determine the intra-annual variability in nutrient regeneration by mussel rope cultures in oligotrophic fjord systems. In situ respiration and nutrient uptake and release rates of $1 \mathrm{~m}$ mussel ropes were measured using 2501 pelagic chambers. There was a 20-fold difference between winter and summer respiration and nutrient release rates. Inorganic nitrogen release ranged from 50 to $1000 \mu \mathrm{mol} \mathrm{h} \mathrm{h}^{-1}$ per meter rope. These variations were mainly related to mussel growth but were also related to changes in water temperature and biofouling biomass (organisms that colonized the mussel ropes). In total 24 genera of fouling organisms were observed, diversity increased over time (ranging from 2 to 12 genera $\mathrm{m}^{-1}$ ), and fouling biomass was mainly characterised by ascidians (max. $37 \pm$ $14 \mathrm{~g} \mathrm{~m}^{-1}$ ). However, mussels dominated the culture ropes, representing $>90 \%$ of total faunal biomass. The amount of organic material associated with the ropes was stable $\left(6.9 \pm 0.3 \mathrm{~g} \mathrm{~m}^{-1}\right)$. At the scale of one mussel farm, nutrient regeneration by mussel rope cultures increased inorganic nitrogen concentrations by $20 \%$ and inorganic phosphorus concentrations by $5 \%$ during summer conditions. During winter, there was no significant effect of mussel cultures on the inorganic nutrient pools. Nutrient regeneration by mussel cultures also affected stoichiometry as nutrients were excreted in dissimilar proportions (nitrogen $>$ phosphate $>$ silicate). The increased nutrient availability may contribute to primary production, especially in nutrient-limited (oligotrophic) fjord ecosystems. However, fjordscale effects are largely dependent on hydrographic conditions of the fjord system.
\end{abstract}

KEY WORDS: Nutrient dynamics · Respiration · In situ · Suspended mussel culture · Biofouling • Pelagic chamber

Resale or republication not permitted without written consent of the publisher

\section{INTRODUCTION}

Suspension feeding bivalves influence the ecosystem by filtration of particulate matter, biodeposition and decomposition of (pseudo-)faeces, and excretion of dissolved metabolites (Prins et al. 1998, Newell 2004, Cranford et al. 2007). Under nutrient limiting conditions inorganic nutrients released by bivalve populations and decomposed pseudofaeces have been argued to stimulate primary production (Asmus \& Asmus 1991, Dame \& Libes 1993, Prins et al. 1998). Indeed, several studies confirmed nutrient release by benthic mineralization underneath mussel farms (Baudinet et al. 1990, Giles et al. 2006, Richard et al. 2007). However, the contribution of benthic mineralization to nutrient availability for pelagic primary pro- 
ducers is largely dependent on the mixing between benthic and euphotic water layers. In shallow areas, the water column is well mixed and benthic released nutrients are available to the pelagic primary producers (Prins \& Smaal 1990, Hatcher et al. 1994). In contrast, in deep culture areas regenerated nutrients are not available to pelagic primary producers, particularly not in cases of profound vertical stratification of the water column. In deep coastal ecosystems, nutrient regeneration in the euphotic zone is therefore most important in the feedback loop from suspended mussel cultures to primary production.

Norwegian fjords are characterised by a deep water column (100 to $1000 \mathrm{~m}$ ), and in spring and summer fjords are stratified as a result of calm wind conditions that restrict vertical mixing of nutrients into the euphotic layer (Aure et al. 1996, Asplin et al. 1999). Nutrients derived from freshwater runoff are generally less important than the vertical mixing of nutrients in Norwegian fjord systems (Aksnes et al. 1989). Consequently, the euphotic zone is nutrient limited for extended periods of the year (Paasche \& Erga 1988, Sætre 2007) resulting in chlorophyll a (chl a) concentrations of generally $<2 \mu \mathrm{g} \mathrm{l}^{-1}$ (Erga 1989a, Aure et al. 2007a). Phytoplankton is the major component of seston along the Norwegian coast (Erga 1989a, Erga et al. 2005, Strohmeier et al. 2009). Primary production rates are typically 100 to $140 \mathrm{~g}$ carbon (C) m-2 $\mathrm{yr}^{-1}$ (Aure et al. 2007a) of which a ratio of 0.4 is regarded as new primary production (Wassmann 1990), resulting in a new carbon supply of 40 to $56 \mathrm{~g} \mathrm{C} \mathrm{m}^{-2} \mathrm{yr}^{-1}$. Norwegian fjords are thereby classified as oligotrophic within the trophic classification of marine systems by Nixon (1995). In this kind of oligotrophic environment, it is essential to understand nutrient regeneration, especially in bivalve culture areas where bivalve growth depends on the availability of phytoplankton.

Studies on nutrient cycling in suspended cultures often focus on (1) benthic mineralization of biodeposits (Baudinet et al. 1990, Giles et al. 2006, Richard et al. 2007), or (2) biochemical processes of the culture itself considering only the mussel biomass (Dowd 2005, Cranford et al. 2007, Brigolin et al. 2009) rather than the whole biological community on the ropes. Besides mussels, suspended mussel cultures comprise a complex habitat of bacteria, epifauna, epiflora, and trapped biodeposits, each contributing to the uptake and release of nutrients (Richard et al. 2006, 2007). The epifauna associated to mussel cultures includes ascidians, barnacles, bryozoans, polychaetes, amphipods and gastropods, of which abundance and species composition vary seasonally (Cayer et al. 1999, Khalaman 2001, Richard et al. 2006, Lutz-Collins et al. 2009). Biodeposits partially accumulate in spaces between mussels on ropes and create a sediment compartment in the water column (Mazouni 2004, Richard et al. 2006). The combined fauna and biodeposit compartment will hereafter be referred to as the 'associated fauna and organic matter' (AFOM) complex (see also Richard et al. 2006).

Nutrient dynamics of complete bivalve culture units indicate that associated fauna contributes to the total nutrient release (LeBlanc et al. 2007) and that AFOM complexes contribute to nitrate, nitrite and silicate fluxes, while the cultivated species, such as Mytilus edulis primarily contribute to ammonia, phosphate and oxygen fluxes (Richard et al. 2006). By investigating 2 year classes and sampling both in August and September, Richard et al. (2006) showed that the relative contribution of the AFOM complex to total nutrient fluxes depends on its composition and thus on farming cycle and season. Furthermore, seasonal variation in AFOM biomass and its composition also influenced nutrient dynamics in oyster cultures (Mazouni et al. 2001). The aforementioned studies were all performed in shallow ecosystems, but in order to better understand nutrient regeneration by suspended mussel cultures, studies in contrasting environments, such as deep oligotrophic fjords, as well as studies covering a full annual cycle are needed.

The objective of this study was to explore the hypothesis of intra-annual variability in nutrient regeneration by blue mussel Mytilus edulis rope culture in the euphotic zone of Norwegian fjord systems. During the course of one year, 2 in situ experiments were conducted simultaneously: (1) an AFOM experiment which focused on quantifying temporal changes in mussel density and the fauna and organic material associated with mussel ropes and (2) a nutrient flux experiment that aimed to quantify temporal variation in oxygen $(\mathrm{O})$, nitrogen $(\mathrm{N})$, phosphate $(\mathrm{P})$ and silicate (Si) fluxes along mussel ropes using large pelagic chambers.

\section{MATERIALS AND METHODS}

Environmental monitoring. Fluorescence, turbidity, temperature and salinity were simultaneously measured at $30 \mathrm{~min}$ intervals at $1.5 \mathrm{~m}$ depth using a STD/CTD 204 (SAIV A/S). Water samples for analysis of seston quantity and quality were taken at $1.5 \mathrm{~m}$ depth at weekly intervals (twice a week during the spring bloom). Particulate organic carbon (POC) and nitrogen (PON), chl $a$ and phaeopigment concentrations were determined by filtering 250 to $500 \mathrm{ml}$ onto a $1.2 \mu \mathrm{m}$ filter (Whatman GF/F). Chl $a$ and phaeopigments were analyzed after extraction with $90 \%$ acetone using the fluorescence method with correction for acidified measurements (Strickland \& Parsons 1968). 
The Model 10-AU fluorometer (Turner Designs) was calibrated with known concentrations of chl a (Sigma Chemicals) and measured spectrophotometrically. Fluorescence measurements were converted to chl a concentrations $\left(\mu \mathrm{g}^{-1}\right)$ to obtain high-resolution chl a time series, using:

chl $a=0.75 \times$ fluorescence $-0.06 \quad\left(r^{2}=0.83, \mathrm{n}=55\right)$

POC/PON concentrations were determined using an NC Analyzer (Thermo Finnigan Flash EA 1112) after drying and fluming the filters over concentrated $\mathrm{HCl}$ for $0.5 \mathrm{~h}$ in a closed container to remove inorganic carbon (Ehrhardt 1983).

Mussel ropes. Mussels used in this study settled in 2007 and were re-socked in February 2008 at a com-

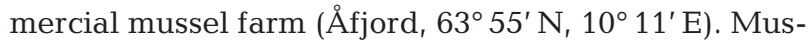
sel ropes consisted of extruded polypropylene rope material (Christmas Tree), attached mussels Mytilus edulis and the AFOM complex. Forty sections of $1 \mathrm{~m}$ rope were transferred to the study site (Austevoll, $60^{\circ}$ $05^{\prime} \mathrm{N}, 05^{\circ} 16^{\prime} \mathrm{E}$ ) in November 2008 and deployed vertically in the water column from $\sim 30 \mathrm{~cm}$ depth. Ten of these sections were used in the nutrient flux study, and the remaining 30 sections were used for the AFOM study (see 'Experimental design'). In May 2009, most mussels were lost due to predation. New mussel rope sections $(1 \mathrm{~m})$ were transferred from the commercial farm to the study site by the end of May 2009. These mussels originated from the same cohort and farming site as the first batch. Ten sections were assigned to the nutrient flux experiments, and 20 sections to the AFOM study.

Experimental design. Two studies were performed from February 2009 to January 2010: (1) an AFOM study, and (2) a nutrient flux study. Within the AFOM study, 4 mussel ropes were collected bimonthly by SCUBA divers. Within the nutrient flux study, repeated measurements on 10 mussel ropes were conducted monthly, with one additional measurement during the spring bloom. Due to the loss of mussels in May 2009, only 5 ropes were included in the May sampling. To compare biomass estimates in both studies, AFOM determinations were also performed on the ropes used for the nutrient flux study $(\mathrm{n}=10)$ following the last sampling in January 2010. Extrapolation of AFOM results to the corresponding oxygen and nutrient fluxes specified the relative contribution of the mussels and AFOM complexes.

Associated fauna and organic material (AFOM) study. To determine mussel and AFOM biomass, mussel ropes were collected by SCUBA divers. A soft polyethylene plastic enclosure $(30 \mathrm{~cm}$ diameter $\times 100 \mathrm{~cm}$ height) was gently raised around the mussel rope so that all organic material associated with a mussel rope was collected within the plastic enclosure. The enclo- sures, including the mussel ropes and water, were transferred to the laboratory where the mussels were removed from the ropes and the organic material was resuspended. The mussels were frozen until the biomass analysis was performed. The suspension was sieved through a $1 \mathrm{~mm}$ sieve and the fauna were collected and preserved with formalin (4\%). The total amount of suspended particulate material (SPM) was determined by filtering subsamples in triplicate onto pre-combusted and weighed filters (Whatman GF/C). Salt was removed from the filters by rinsing with deionised water. Filters were dried at $60^{\circ} \mathrm{C}$ overnight and weighed to obtain SPM values. The filters were combusted at $450^{\circ} \mathrm{C}$ for $6 \mathrm{~h}$ to determine fractions of organic (POM) and inorganic (PIM) particulate matter. Additional subsamples were taken to determine the quality of the organic material: POC, PON, chl a and phaeopigments (see 'Environmental monitoring' above). Mussel samples were subsampled to determine the total number of mussels on a rope and the length and weight of individual mussels. Individual length was measured with a digital caliper $( \pm 0.01$ $\mathrm{mm})$, and tissue was removed from the shells and dried for at least $72 \mathrm{~h}$ at $60^{\circ} \mathrm{C}$ to determine dry weight (DW). These tissue samples were also combusted at $450^{\circ} \mathrm{C}$ for $6 \mathrm{~h}$ to determine ash-free dry weight (AFDW). Fauna determinations were performed to genus level, since we are mainly interested in the functional role of the associated organisms. A similar protocol for DW and AFDW estimation as described above for mussels was applied to the fauna samples.

In situ nutrient flux study. Incubations with pelagic chambers were conducted to determine oxygen and nutrient fluxes along the mussel rope interface. The pelagic chambers consisted of 2501 rigid white polyethylene tanks $(50 \mathrm{~cm}$ diameter $\times 150 \mathrm{~cm}$ height with conical shaped bottoms) that could be sealed off from the bottom and the top (Fig. 1). A pump was mounted inside each chamber to mix the water, and flow was regulated $\left(101 \mathrm{~min}^{-1}\right)$ in order to minimize resuspension of organic material. Homogenous mixing was confirmed by measuring nutrient concentrations simultaneously at 16 positions within the chamber. An oxygen optode (no. 4835, Aanderaa) and STD/CTD were mounted into one of the chambers to record oxygen and fluorescence concentrations at $2 \mathrm{~s}$ intervals during the incubations.

In total 6 pelagic chambers were used, allowing simultaneous sampling of 5 ropes and 1 control. The control consisted of a pelagic chamber filled with water but without a mussel rope and was used to correct for fluxes other than those caused by mussel rope metabolism. To sample all 10 ropes, 2 sets of incubations were performed during one day or on 2 subsequent days, depending on incubation time. When deploying the 


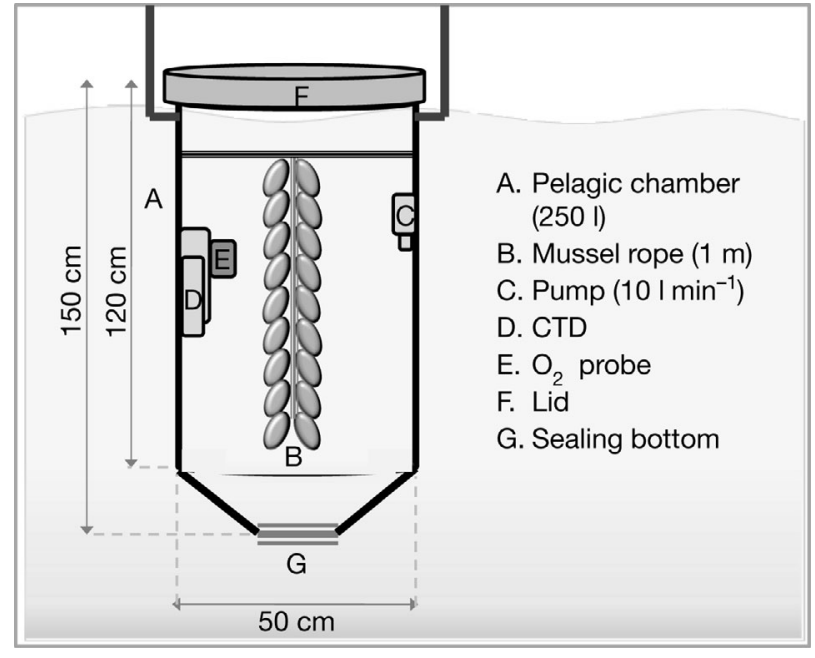

Fig. 1. Pelagic chamber used for the in situ oxygen and nutrient flux measurements of mussel ropes

chambers, both bottom and top were opened, and the chambers were gently raised around the mussel ropes, minimizing water movement around the ropes. Incubations started when both the bottom and top were sealed and ended when the oxygen concentration had decreased by $10 \%$ when compared to initial values. Total incubation time varied between 0.5 and $6 \mathrm{~h}$, depending on the season. Oxygen measurements and water samples for dissolved inorganic nutrient concentrations were taken in all chambers at the start and end of each incubation. Dissolved inorganic nutrient samples $(20 \mathrm{ml})$, other than total ammonia nitrogen (TAN), were preserved with chloroform and stored in a cool and dark place until analysis. Those samples were analyzed according to standard methods (Parsons et al. 1992) adapted for an auto-analyzer. TAN samples (20 ml) were frozen immediately until used for analysis (Holmes et al. 1999). TAN concentrations were analyzed by means of fluorometric analysis (Kerouel \& Aminot 1997, Holmes et al. 1999).

Fluxes were determined by the difference between the start and the end values and multiplied by the chamber volume. Linear decline in oxygen concentration was confirmed by the continuous oxygen measurements in one of the pelagic chambers during each incubation. Finally, fluxes were corrected for the fluxes measured in the control chamber, even though the control fluxes were negligible compared to those measured on the mussel ropes.

Statistical analysis. All data were checked for homogeneity and normality of variance assumptions by (1) visually examining standardised residuals versus predicted values plots and Q-Q plots of residuals, (2) Shapiro-Wilk tests and (3) Levene tests (Quinn \&
Keough 2002). When one of the assumptions was violated, appropriate data transformations were performed. In cases where transformations did not lead to acceptance of the assumptions, nonparametric tests were performed. Statistical analyses were performed using SAS 9.1, and all data are presented as mean \pm $\mathrm{SE}$, unless stated otherwise.

One-way analysis of variance (ANOVA) tests were used to test the temporal variation in mussel and AFOM parameters in the AFOM study. The effect of time (sampling month) was tested for the following variables separately: mussel density, mussel weight, mussel length, faunal biomass (square root transformations), amount (POM) and quality of organic material (POC and PON, log transformations). In case of significant results, Tukey's HSD post-hoc multiple comparison tests were used to determine which of the sampling months were significantly different from each other. A nonparametric Kruskal-Wallis test followed by pairwise comparisons with Mann-Whitney $U$-tests were used to test the temporal variation in the number of faunal genera.

We used $t$-tests to test whether mussel ropes used in the AFOM and the nutrient study were similar. For the following variables, separate $t$-tests were used to test for variation in mussel density, mussel weight, mussel length, faunal biomass, number of faunal genera, amount of organic material (POM) and the quality of organic material (POC, PON, chl a, phaeopigments). A nonparametric Kruskal-Wallis test was performed for the C:N ratio of organic matter. Pearson's correlation analysis was used to identify whether oxygen consumption and nutrient release rates were significantly related to mussel biomass.

Stoichiometric comparisons of N:P (in atomic equivalents) were made for the ambient water and nutrient fluxes by performing repeated measures ANOVAs. The sampling months (time) comprised the within-factor treatment, and the 2 stoichiometric variables (ambient and flux) comprised the between-factor treatment. In addition, statistical significance was estimated from the Greenhouse-Geisser adjusted probability to avoid violating the assumption of sphericity of the withinsubject (time) variance-covariance matrix (Field 2005).

\section{RESULTS}

\section{Environmental conditions}

Temperature ranged from $3^{\circ} \mathrm{C}$ in February to $19^{\circ} \mathrm{C}$ in the beginning of July (Fig. 2A). The spring bloom started in late February and lasted for $\sim 2 \mathrm{wk}$ (Fig. 2A). Maximum chl a values were recorded in the first week of March $\left(7.7 \mu \mathrm{g} \mathrm{l}^{-1}\right)$. Chl a concentrations varied 

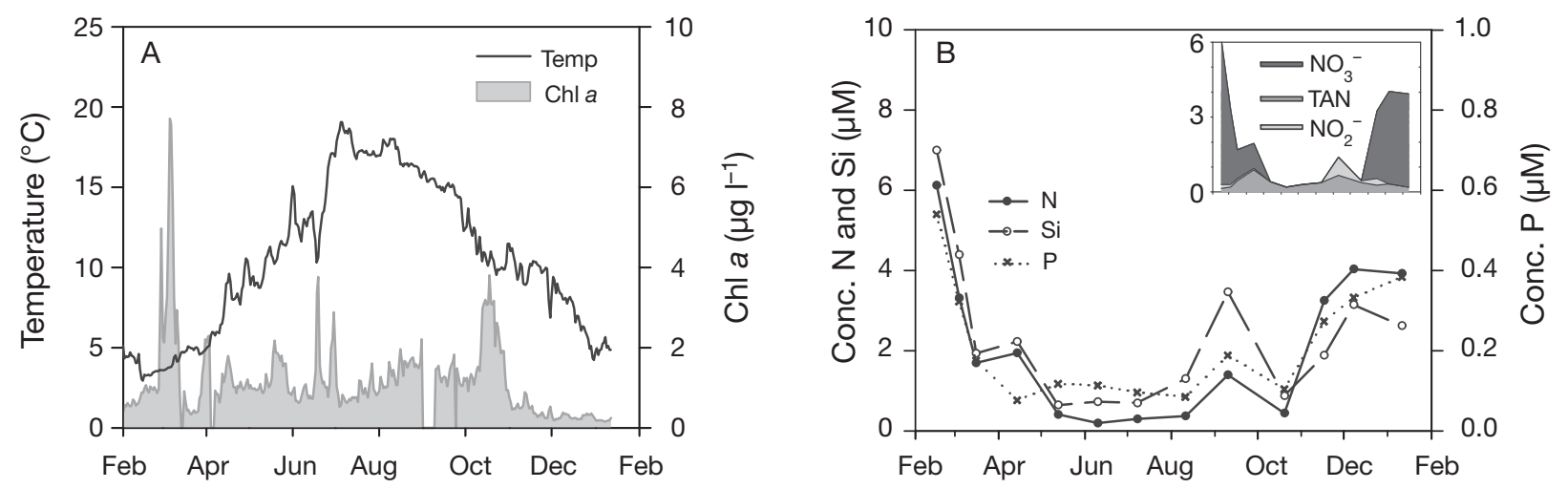

Fig. 2. Changes in environmental conditions measured in the water column at the study site from February 2009 to January 2010. (A) Daily averages of phytoplankton ( $\mathrm{chl} \mathrm{a}$ ) and temperature, (B) monthly measurements of dissolved inorganic nitrogen (N), phosphate $(\mathrm{P})$ and silicate $(\mathrm{Si})$ concentrations. Inset represents fractionation of nitrogen flux into nitrate $\left(\mathrm{NO}_{3}^{-}\right)$, nitrite $^{-}\left(\mathrm{NO}_{2}^{-}\right)$and total ammonia nitrogen (TAN)

between 1 and $2 \mu \mathrm{g} \mathrm{l^{-1 }}$ from mid-March to October, followed by an autumn bloom in October (max. $3.8 \mu \mathrm{g}$ $\mathrm{l}^{-1}$ ). From November to January chl a concentration was below $0.5 \mu \mathrm{g} \mathrm{l}^{-1}$. Salinity was $29.7 \pm 1.6 \mathrm{ppt}$ (mean $\pm \mathrm{SD}$ ) throughout the study period. Dissolved phosphate, silicate and inorganic nitrogen concentrations were highest in winter and lowest in summer (Fig. 2B). Total inorganic nitrogen was calculated as the sum of TAN, nitrate and nitrite. Nitrate values, however, dominated the pattern for total nitrogen concentrations (Fig $2 \mathrm{~B}$ inset). During the study, concentrations of POC and PON ranged from 45 to 546 and 6 to $52 \mu \mathrm{g} \mathrm{l^{-1 }}$, respectively. The highest values were recorded in spring and summer and decreased during autumn, and the lowest values were recorded in winter. Seasonal changes in POC and PON followed a parallel pattern and hence $\mathrm{C}: \mathrm{N}$ ratios showed little variation (mean $\pm \mathrm{SD}$ : $8.9 \pm$ 1.6).

\section{Mussel biomass}

Individual mussel weight (AFDW) doubled from March 2009 to January 2010 (Fig. 3), and although weight decreased from October to January, this change was not significant (Tukey; p < 0.05). Average length increased from $33 \pm 1$ to $50 \pm 2 \mathrm{~mm}$ (Fig. 3). Interpolating individual mussel weight to determine mussel density on the ropes used in the flux study $\left(543 \pm 23 \mathrm{~m}^{-1}\right)$ resulted in average biomass estimates of $118 \mathrm{~g} \mathrm{~m}^{-1}$ in February 2009 and reached $301 \mathrm{~g} \mathrm{~m}^{-1}$ in January one year later. There were no significant differences in density $\left(t\right.$-test; $\left.F_{1,12}=3.31, \mathrm{p}=0.094\right)$, length $\left(t\right.$-test $F_{1,12}=$ $3.70, \mathrm{p}=0.079$ ) and weight ( $t$-test; $F_{1,12}=0.76, \mathrm{p}=0.400$ ) between mussel ropes used in the AFOM or in the nutrient flux study in January 2010.

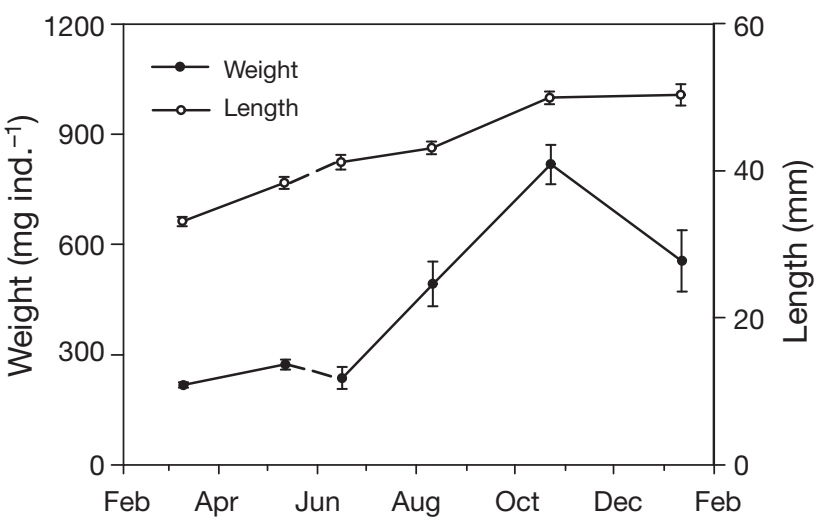

Fig. 3. Mytilus edulis. Average ( $\pm \mathrm{SE})$ individual mussel length and weight (ash-free dry weight) from February 2009 to January 2010. Dashed lines between May and June indicate the 2 separate mussel batches

\section{AFOM composition and biomass}

The biomass and composition of fauna associated with the mussel ropes increased significantly during the study (Table 1). The total faunal biomass (AFDW) excluding mussels varied from $0.10 \pm 0.03 \mathrm{~g} \mathrm{~m}^{-1}$ in June to $37.66 \pm 14.07 \mathrm{~g} \mathrm{~m}^{-1}$ in October. The difference in faunal biomass of the second batch (mussel ropes obtained in June) compared to the first batch (March to May) was considered to be negligible in the context of biomass increases observed later during the study period. Additionally, similar genera were observed between the 2 batches, indicating that the 2 batches were comparable in terms of faunal type and biomass. At the end of the study, in January, no statistical difference in faunal biomass was found between the ropes used in the AFOM study and the ropes used in the 
nutrient flux study ( $t$-test $\left.F_{i 112}=0.83, \mathrm{p}=0.380\right)$. In total, 24 genera were identified, with a maximum mean number of $\sim 12$ genera observed per meter rope. The faunal composition consisted both of sedentary and errant species. Sedentary fauna accounted for most of the faunal biomass and was predominantly represented by the ascidian Ciona intestinalis. Settlement of juvenile $C$. intestinalis was observed in August followed by a rapid increase in biomass. Maximum biomass was measured in October, but this level was assumed to have already been reached in September (H. M. Jansen pers. obs.). Towards the end of the study (October to January) $>90 \%$ of the total faunal biomass was represented by ascidians. Abundance of bryozoans and the ascidian Botryllus also increased over time (H. M. Jansen pers. obs.). The polychaetes Harmothoe and Nereis were the most abundant errant species. In January, the average biomass was $0.44 \pm$ 0.09 and $0.68 \pm 0.25 \mathrm{~g} \mathrm{~m}^{-1}$ for those 2 genera, respectively, which corresponded to 10 to 12 ind. $\mathrm{m}^{-1}$. Not all individuals were identified to species level, but it seemed that Nereis diversicolor dominated the Nereis genus.

The average amount (AFDW) of organic material associated with mussel ropes was $6.9 \pm 0.3 \mathrm{~g} \mathrm{~m}^{-1}$ (Table 2) and did not show significant differences between sample dates $\left(\right.$ ANOVA $_{i} F_{5,18}=2.53, \mathrm{p}=$ 0.067). The $\mathrm{C}: \mathrm{N}$ ratio of the organic material did not differ between sample dates (Kruskal-Wallis; $\mathrm{p}=$ 0.071), while the phaeopigment:chl a ratio varied between sampling dates $\left(\right.$ ANOVA; $_{4} F_{4,15}=6.05, \mathrm{p}=$ 0.004). The October sample showed significantly higher values compared to those from March, May and June (Tukey; $\mathrm{p}<0.05)$. The above result indicates that

Table 1. Average ( $\pm \mathrm{SE}$ ) biomass of (A) sedentary and (B) errant fauna ( $\mathrm{g}$ ashfree dry weight) associated with blue mussel Mytilus edulis ropes used in the associated fauna and organic material (AFOM) study ( $\mathrm{n}=4$ ropes per sampling point) and nutrient flux study ( $\mathrm{n}=10$ ropes). Data are standardized to mussel ropes of $1 \mathrm{~m}$ length, and fauna were identified to genus unless otherwise noted. Standard error is only provided when a faunal genus was found on more than one replicate rope. Different superscript letters indicate significant differences $(\mathrm{p}<0.05)$. indet.: indeterminate

\begin{tabular}{|c|c|c|c|c|c|c|c|}
\hline & \multicolumn{6}{|c|}{ - AFOM study - } & \multirow{2}{*}{$\begin{array}{l}\text { Flux study } \\
\text { Jan }\end{array}$} \\
\hline & Mar & May & Jun & Aug & Oct & Jan & \\
\hline \multicolumn{8}{|l|}{ Sedentary fauna } \\
\hline Anthozoa, indet. ${ }^{\text {III }}$ & & & & 0.01 & & & $0.05 \pm 0.02$ \\
\hline Ascidiacea, Ascidiella & & & & & $0.09 \pm 0.07$ & $0.19 \pm 0.12$ & $0.04 \pm 0.03$ \\
\hline Ascidiacea, Botryllus ${ }^{\mathrm{I}}$ & & & & Present & Present & Present & Present \\
\hline Ascidiacea, Ciona & $0.45 \pm 0.39$ & $0.67 \pm 0.36$ & $0.02 \pm 0.01$ & $1.15 \pm 0.41$ & $36.50 \pm 14.00$ & $21.24 \pm 9.43$ & $30.29 \pm 5.34$ \\
\hline Ascidiacea, Styela & 0.15 & & & & & & 0.01 \\
\hline Bivalvia, Hiatella & & $0.13 \pm 0.05$ & & & & & \\
\hline Echinoidea, Psammachinus & & & & 0.01 & 0.09 & 0.03 & $0.10 \pm 0.06$ \\
\hline Gymnolaemata, Electra ${ }^{\mathrm{I}}$ & Present & Present & & Present & Present & Present & Present \\
\hline Gymnolaemata, indet. I,III & & & & Present & Present & Present & Present \\
\hline Polychaeta, Capitella & & & & & & & $<0.01$ \\
\hline Polychaeta, Neoamphitrite & & & & & $0.09 \pm 0.05$ & $<0.01$ & $0.09 \pm 0.03$ \\
\hline Total sedentary fauna & $0.60 \pm 0.54$ & $0.80 \pm 0.33$ & $0.02 \pm 0.01$ & $1.18 \pm 0.41$ & $36.76 \pm 13.98$ & $21.46 \pm 9.33$ & $30.60 \pm 5.36$ \\
\hline \multicolumn{8}{|l|}{ Errant fauna } \\
\hline Anopla, Longissimus & & & & 0.02 & & & 0.02 \\
\hline Crustacea, Gammarus & $<0.01$ & $<0.01$ & $<0.01$ & 0.01 & $<0.01$ & & \\
\hline Crustacea, Brachyura ${ }^{\mathrm{II}}$ & & & & & 0.01 & $0.01 \pm 0.01$ & $0.03 \pm 0.02$ \\
\hline Crustacea, Galatheidae ${ }^{\mathrm{II}}$ & & & & $<0.01$ & $0.10 \pm 0.03$ & $0.19 \pm 0.06$ & $0.07 \pm 0.02$ \\
\hline Crustacea, Idoteidae & $<0.01$ & & & & $<0.01$ & $0.01 \pm 0.01$ & $<0.01$ \\
\hline Crustacea, Porcellanidae ${ }^{\mathrm{II}}$ & & & & & & $0.10 \pm 0.03$ & $0.07 \pm 0.02$ \\
\hline \multicolumn{8}{|l|}{ Gastropoda Facelina } \\
\hline Polychaeta, Kefersteinia & & & & & & & $0.03 \pm 0.01$ \\
\hline Polychaeta, Syllidia & & & & & & & $0.01 \pm 0.00$ \\
\hline Polychaeta, Eunoe & & $<0.01$ & & & & 0.01 & \\
\hline Polychaeta, Lepidonotus & $0.01 \pm 0.01$ & & & & 0.01 & & \\
\hline Polychaeta, Harmothoe & $0.02 \pm 0.02$ & $0.12 \pm 0.04$ & $0.05 \pm 0.02$ & $0.12 \pm 0.02$ & $0.38 \pm 0.13$ & $0.44 \pm 0.09$ & $0.73 \pm 0.07$ \\
\hline Polychaeta, Nereis & $0.05 \pm 0.03$ & 0.04 & 0.02 & $0.20 \pm 0.07$ & $0.40 \pm 0.09$ & $0.68 \pm 0.25$ & $0.89 \pm 0.16$ \\
\hline Total errant fauna & $0.09 \pm 0.05$ & $0.17 \pm 0.03$ & $0.07 \pm 0.02$ & $0.35 \pm 0.08$ & $0.90 \pm 0.14$ & $1.44 \pm 0.29$ & $1.85 \pm 0.16$ \\
\hline $\begin{array}{l}\text { Total biomass associated } \\
\text { fauna }\end{array}$ & $0.69 \pm 0.55^{\mathrm{b}}$ & $0.97 \pm 0.36^{b}$ & $0.10 \pm 0.03^{\mathrm{a}}$ & $1.53 \pm 0.36^{\mathrm{b}}$ & $37.66 \pm 14.07^{\mathrm{c}}$ & $22.90 \pm 9.50^{c}$ & $32.44 \pm 5.44$ \\
\hline $\begin{array}{l}\text { Total number of associated } \\
\text { faunal genera }\end{array}$ & $3.75 \pm 1.03^{\mathrm{a}}$ & $3.25 \pm 0.63^{\mathrm{a}}$ & $2.00 \pm 0.41^{\mathrm{a}}$ & $7.25 \pm 0.48^{\mathrm{b}}$ & $9.75 \pm 0.25^{c}$ & $10.25 \pm 0.48^{\mathrm{c}}$ & $12.10 \pm 0.64^{c}$ \\
\hline $\begin{array}{l}\text { Biomass fauna/biomass } \\
\text { mussels }(\%)\end{array}$ & 0.5 & 0.4 & 0 & 0.4 & 8.3 & 7.1 & 8.2 \\
\hline
\end{tabular}


Table 2. Average $( \pm \mathrm{SE})$ quantity and quality of organic material associated with blue mussel Mytilus edulis ropes used in the associated fauna and organic material (AFOM) study ( $\mathrm{n}=4$ ropes per sampling point) and nutrient flux study ( $\mathrm{n}=10$ ropes). Different supercript letters indicate significant differences $(\mathrm{p}<0.05)$. There were no significant differences between the monthly values of the AFOM study for POM, C:N and chlorophyll a (chl a). POM: particulate organic material; OM: organic material (relative to total particulate material); POC: particulate organic carbon; PON: particulate organic nitrogen. nd: no data available

\begin{tabular}{|c|c|c|c|c|c|c|c|c|}
\hline Month & $\begin{array}{c}\mathrm{POM} \\
\left(\mathrm{g} \mathrm{m}^{-1}\right)\end{array}$ & $\begin{array}{l}\mathrm{OM} \\
(\%)\end{array}$ & $\begin{array}{c}\text { POC } \\
\left(\mathrm{mg} \mathrm{g}^{-1} \mathrm{OM}\right)\end{array}$ & $\begin{array}{c}\text { PON } \\
\left(\mathrm{mg} \mathrm{g}^{-1} \mathrm{OM}\right)\end{array}$ & $\begin{array}{l}\mathrm{C}: \mathrm{N} \\
\text { ratio }\end{array}$ & $\begin{array}{c}\mathrm{Chl} \mathrm{a} \\
\left(\mathrm{mg} \mathrm{g}^{-1} \mathrm{OM}\right)\end{array}$ & $\begin{array}{c}\text { Phaeopigment } \\
\left.\text { (mg g }{ }^{-1} \mathrm{OM}\right)\end{array}$ & $\begin{array}{l}\text { Phaeopigment: } \\
\text { chl a ratio }\end{array}$ \\
\hline \multicolumn{9}{|l|}{ AFOM study } \\
\hline Mar & $6.1 \pm 0.3$ & 21 & $257 \pm 13^{a}$ & $32 \pm 1^{\mathrm{abc}}$ & 9.3 & $1.2 \pm 0.4$ & $2.3 \pm 0.4^{\mathrm{b}}$ & $2.1^{\mathrm{a}}$ \\
\hline May & $8.8 \pm 0.4$ & 29 & $120 \pm 37^{b}$ & $18 \pm 5^{a}$ & 7.8 & $0.8 \pm 0.1$ & $0.8 \pm 0.1^{\mathrm{a}}$ & $0.9^{\mathrm{a}}$ \\
\hline Jun & $8.4 \pm 0.3$ & 26 & $420 \pm 54^{\mathrm{a}}$ & $50 \pm 9^{d c}$ & 10.4 & $1.2 \pm 0.7$ & $1.9 \pm 0.3^{\mathrm{ab}}$ & $1.9^{\mathrm{a}}$ \\
\hline Aug & $6.6 \pm 0.6$ & 32 & $113 \pm 15^{b}$ & $18 \pm 3^{\text {ba }}$ & 7.6 & nd & nd & nd \\
\hline Oct & $5.3 \pm 0.8$ & 21 & $587 \pm 107^{a}$ & $82 \pm 16^{\mathrm{d}}$ & 8.5 & $0.7 \pm 0.3$ & $4.4 \pm 0.3^{\mathrm{c}}$ & $6.8^{\mathrm{b}}$ \\
\hline Jan & $5.9 \pm 0.4$ & 21 & $319 \pm 60^{\mathrm{a}}$ & $42 \pm 8^{b c d}$ & 8.9 & $0.3 \pm 0.2$ & $1.0 \pm 0.3^{\mathrm{ab}}$ & $4.9^{\mathrm{ab}}$ \\
\hline \multicolumn{9}{|l|}{ Nutrient flux study } \\
\hline Jan & $12.7 \pm 0.7$ & 35 & $461 \pm 29$ & $66 \pm 4$ & 8.1 & $0.5 \pm 0.0$ & $1.7 \pm 0.2$ & 3.9 \\
\hline
\end{tabular}

there was no difference between the 2 mussel batches (March to May vs. June to January) in terms of quantity and quality of the organic material associated with the ropes. Almost twice as much organic material was found on the ropes used in the flux study compared to the AFOM study ( $t$-test; $\left.F_{1,12}=11.69, \mathrm{p}=0.005\right), \mathrm{C}: \mathrm{N}$ ratios were significantly different (Kruskal-Wallis; $\mathrm{p}=$ 0.034), and phaeopigment:chl a ratios were not significantly different ( $t$-test; $F_{1,12}=0.40 ; \mathrm{p}=0.538$ ) between the nutrient flux and AFOM studies.

\section{Oxygen and nutrient fluxes}

Continuous oxygen measurements within the pelagic chambers confirmed a linear decrease throughout the incubations. Oxygen consumption was lowest in February $\left(0.6 \pm 0.1 \mathrm{mmol} \mathrm{h}^{-1}\right)$, increased until maximum values in October $\left(12.8 \pm 0.8 \mathrm{mmol} \mathrm{h}^{-1}\right)$, and decreased again during the winter months to $2.4 \pm$ $1.3 \mathrm{mmol} \mathrm{h}^{-1}$ in January (Fig. 4A).

As for oxygen consumption, the general pattern in nutrient release, except for silicate, showed a significant increase during the spring bloom, followed by an increase until late summer and a decrease during the subsequent months (Fig. 4B). TAN release increased in August and September to maximum values of $946.7 \pm$ $105.2 \mu \mathrm{mol} \mathrm{h} \mathrm{h}^{-1}$. TAN releases completely dominated the total dissolved nitrogen fluxes as nitrite and nitrate fluxes were low, often below the detection limit of the instruments $\left(0.5\right.$ and $0.05 \mu \mathrm{mol} \mathrm{l}^{-1}$ for nitrate and nitrite, respectively). As for oxygen and nitrogen, an increase in phosphate release was observed during the spring bloom. Oxygen consumption and TAN release remained at similar levels in the months following the spring bloom while phosphate release decreased (Fig. 4C). The highest phosphate release rates were observed in summer with maximum values in September $\left(62.7 \pm 7.7 \mu \mathrm{mol} \mathrm{h}{ }^{-1}\right)$. No apparent seasonal pattern in silicate fluxes was observed (Fig. 4D). Uptake of silicate was observed in February and the beginning of March. After that, silicate fluxes varied around zero except for some outlying values in September and October.

Variation in oxygen consumption and ammonia releases were related to mussel biomass as significant positive correlation coefficients were observed between mussel biomass and oxygen $(r=0.68, p=0.010)$ or TAN ( $\mathrm{r}=0.66, \mathrm{p}=0.014)$ fluxes.

$\mathrm{N}: \mathrm{P}$ ratios varied significantly both throughout the season (repeated measures ANOVA, p < 0.0001) and between ambient water and flux measurements (repeated measures ANOVA, $p=0.0008$ ) (Fig. 5). On average, the N:P flux ratios were 3 times higher compared to ambient values. As no substantial silicate fluxes were observed (Fig. 4), N:Si and P:Si ratios could not be calculated. However, nitrogen and phosphate were evidently excreted in higher amounts than silicate.

\section{DISCUSSION}

This study presents new data on the seasonal dynamics of nutrient release rates from suspended mussel cultures in relation to the succession of mussel biomass, species composition and abundance of fauna, and organic material associated with mussel rope cultures in an oligotrophic fjord environment.

\section{AFOM succession}

The settlement of different ascidian, polychaete and crustacean genera reflected a significant increase in 

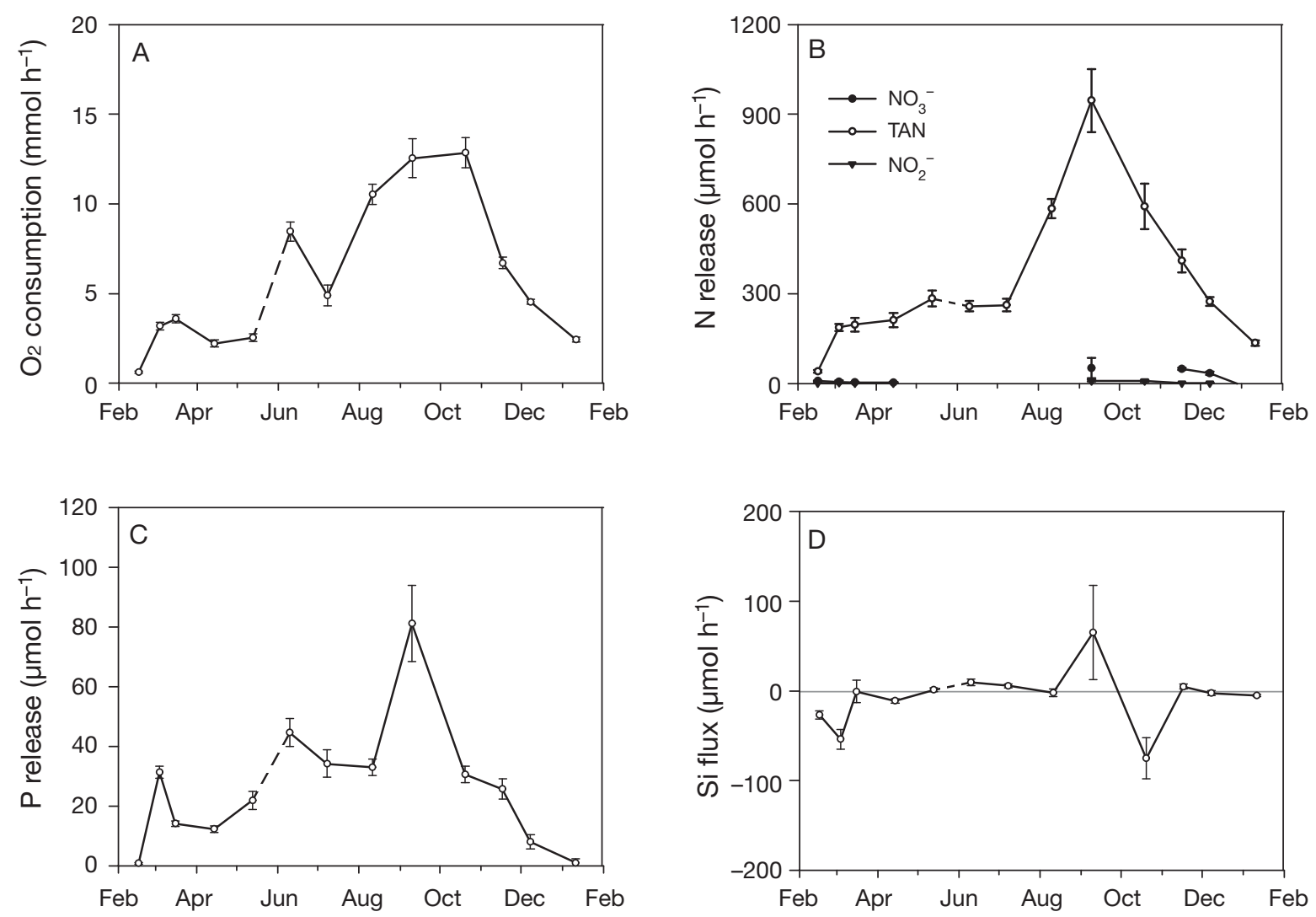

Fig. 4. Mytilus edulis. Average $( \pm \mathrm{SE})(\mathrm{A})$ oxygen consumption, (B) $\mathrm{N}$ release of nitrate $\left(\mathrm{NO}_{3}{ }^{-}\right)$, nitrite $\left(\mathrm{NO}_{2}{ }^{-}\right)$, and total ammonia nitrogen (TAN), (C) phosphate release and (D) silicate uptake and release from mussel ropes measured in situ with pelagic chambers from February 2009 to January 2010 ( $n=10$ ropes per sampling point). Data are standardized to ropes of $1 \mathrm{~m}$ length.

Dashed lines between May and June indicate the 2 separate mussel batches

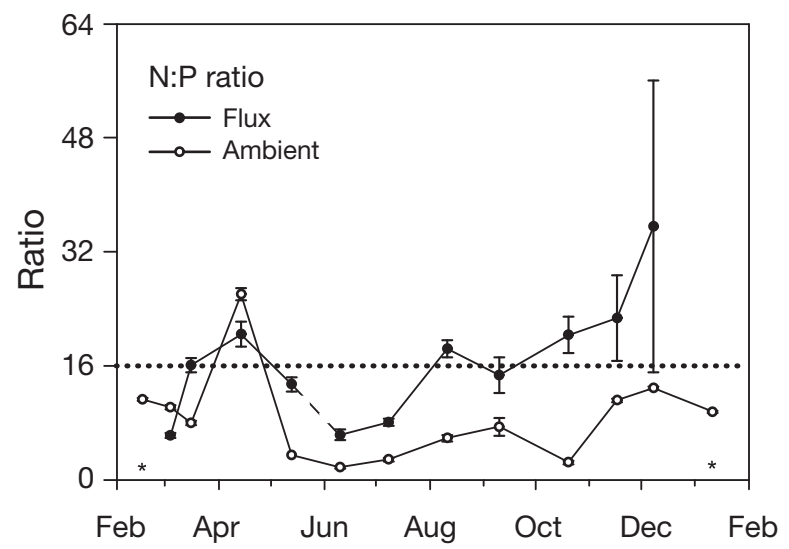

Fig. 5. Mytilus edulis. Average ( \pm SE) N:P ratio of the ambient water (see Fig. 2B) and nutrient release rates per hour by mussel ropes (see Fig. 4) measured from February 2009 to January 2010 ( $\mathrm{n}=10$ per sampling point). An asterisk indicates sampling dates for which phosphate release rates were too low to calculate representative N:P ratios. Dashed line between May and June indicates the 2 separate mussel batches, the thick dotted line the Redfield's elemental ratio $(\mathrm{N}: \mathrm{P}=16)$ taxonomic richness throughout the study period. This result agreed with those of Taylor et al. (1997), Richard et al. (2006) and Lutz-Collins et al. (2009), which showed that number and composition of fauna associated to bivalve cultures are dependent on culture duration. Intra-annual variation in associated faunal abundance in suspended oyster culture showed similar patterns as those observed in our study (Mazouni et al. 2001), but they observed summer mortality of fouling ascidians due to anoxic (bottom) conditions. The average number of faunal genera associated with mussel ropes found in our study $\left(6.9 \pm 1.5 \mathrm{~m}^{-1}\right)$ was comparable to average values of 7 to 10 genera per $25 \mathrm{~cm}$ rope found by Richard et al. (2006). However, the 4 times longer mussel rope sections used in our study may have resulted in higher faunal diversity, because diversity is spatially dependent. Biomass estimates for associated fauna were $\sim 60$-fold higher in our study compared to the estimates of Richard et al. (2006) and were still 4-fold higher when the biomass of Ciona intestinalis was excluded from our estimates. The proportion 
of the fouling biomass relative to mussel biomass found in our study ( 0 to $8 \%$ ) was at the same magnitude as that reported for commercial mussel farming in Canada (LeBlanc et al. 2007). Although taxonomic richness increased with time, abundance was dominated by the ascidian $C$. intestinalis (>90\%). Ascidians, and especially $C$. intestinalis, are well-known fouling organisms in bivalve cultures (see McKindsey et al. 2009 for review).

The presence of the deposit-feeding polychaetes Capitella and Neoamphitrite indicates that mussel ropes contain a large amount organic material (Grassle \& Grassle 1974, Pearson \& Rosenberg 1978). This study confirmed that suspended bivalve cultures form a sediment compartment in the water column (Arakawa 1990, Mazouni et al. 2001, Richard et al. 2006). However, this study is the first to quantify the amount of organic material associated with mussel ropes. The organic material associated with mussel ropes was stable throughout the study period $\left(6.9 \pm 0.3 \mathrm{~g} \mathrm{~m}^{-1}\right)$. As the biomass of mussels and, subsequently, faeces production increased during the culture cycle, settlement of faeces fragments on mussel ropes seems space limited and hence a high fraction of the total produced faeces will sink towards the seabed, as observed in shallow systems (Grant et al. 2005, Callier et al. 2006, Giles et al. 2009, Weise et al. 2009). Fouling ascidians may significantly enhance sedimentation from suspended mussel farms (McKindsey et al. 2009), but the development of ascidian populations from August onwards did not increase organic loading on the mussel ropes itself in our study, further indicating that settlement of organic material on mussel ropes is space limited.

\section{Oxygen consumption and nutrient release}

This study showed significant temporal variation in oxygen consumption and nutrient release rates along the mussel rope interface during one annual cycle. Differences between minimum and maximum rates varied up to 20 times. The in situ method using pelagic chambers was chosen to minimize movement of the mussel and water displacement around the ropes, prevent resuspension of trapped organic matter and minimize changes in mussel behaviour, thus allowing us to study intact mussel ropes under natural conditions. The length of the chambers $(1.5 \mathrm{~m})$ developed for this study allowed us to study mussel rope sections of $1 \mathrm{~m}$ length, which is at least 4 -fold larger than previous studies on biochemical processes along mussel ropes (Richard et al. 2006, 2007) and permitted us to better integrate spatial variability in AFOM biomass and diversity.
Linking oxygen consumption and nutrient release to temporal changes in environmental conditions, mussel growth, and succession of AFOM complexes provides insight into the relative contribution of each compartment to the oxygen consumption and nutrient uptake or release from the mussel rope interface. Although biomass of the fouling organisms increased significantly throughout the study period, mussels were always the dominating species on the ropes. Even during maximum ascidian abundance, $>90 \%$ of the faunal biomass (epifauna and mussels) was represented by mussels.

Metabolic processes in mussels are weight dependent (Smaal et al. 1997), and part of the annual variation in respiration and TAN release rates was explained by growth of the mussels throughout the year. Mussel metabolism is also correlated to temperature (Widdows \& Bayne 1971, Vooys 1976) and food (Bayne et al. 1989, 1993), although direct correlation to any of those factors is often difficult due to the interrelationship between food and temperature (Grant 1996, Smaal et al. 1997). The increased release rates during the spring bloom, maximum levels in September followed by a gradual decrease in the subsequent months as observed in our study is in accordance with Strohmeier (2009). That study showed that temperature and respiration were positively correlated for individual mussels grown in oligotrophic areas during autumn and winter, but these parameters were uncoupled during spring when food concentrations suddenly increased due to the spring bloom of phytoplankton. In our study, maximum respiration and nutrient release rates were observed in September, which did not coincide with maximum temperature (August) or elevated food levels. However, biomass of associated fauna (ascidians) was high from September onwards. The ecological functioning of ascidians is similar to mussels (Petersen 2007) and the high abundance of fouling ascidians indicates a source of nutrients. As for mussels, ascidian metabolism is temperature dependent (Goodbody 1974), although little quantitative data is available. Nevertheless, lower nutrient release rates are expected with decreasing temperatures (e.g. from September to October).

The maximum mussel rope oxygen consumption rates (standardised to g AFDW) measured in September in our study, were lower than those of mussel ropes in Canada during the same season $\left(39 \mu \mathrm{mol} \mathrm{h}{ }^{-1} \mathrm{~g}^{-1}\right.$ in our study compared to values between 55 and $75 \mu \mathrm{mol}$ $\mathrm{h}^{-1} \mathrm{~g}^{-1}$ AFDW reported by Richard et al. 2006). Hence, lower values were observed despite considerably more fauna being associated with the ropes in our study. TAN release rates measured in our study $\left(2.5 \mu \mathrm{mol} \mathrm{h} \mathrm{h}^{-1}\right.$ $\mathrm{g}^{-1}$; September) were comparable to values reported by Richard et al. (2006) in September $\left(2.5 \mu \mathrm{mol} \mathrm{h} \mathrm{h}^{-1} \mathrm{~g}^{-1}\right.$, 
while release rates measured in August in their study were $>5$ times higher $\left(14 \mu \mathrm{mol} \mathrm{h}{ }^{-1} \mathrm{~g}^{-1}\right)$. These high TAN fluxes were explained by protein catabolism of the mussels that were in poor post-spawning condition and decomposition of dead mussels (Richard et al. 2006). Almost no dying mussels were observed during our study and because the main spawning events in Norway occur in May and June (Duinker et al. 2008), such factors did not influence the summer values used for comparison here. Phosphate release rates were comparable between our study and Richard et al. (2006; $0.2 \mu \mathrm{mol} \mathrm{h}^{-1} \mathrm{~g}^{-1}$ AFDW). Population-based estimates were also carried out by Prins \& Smaal (1990, 1994) on mussel beds (including AFOM complexes) in the Oosterschelde estuary in the Netherlands. When TAN and phosphate fluxes are standardized to a mussel biomass similar to our ropes, release rates of the mussel beds were 6.0 and $0.3 \mu \mathrm{mol} \mathrm{h}^{-1} \mathrm{~g}^{-1}$ for TAN and phosphate, respectively. These rates are 3 to 5 -fold higher than yearly averages observed in our study $(1.2$ and $0.1 \mu \mathrm{mol} \mathrm{h}{ }^{-1} \mathrm{~g}^{-1}$ for TAN and phosphate, respectively). Enhanced release rates observed in the mussel beds might be induced by higher food availability in the Oosterschelde and related enhanced metabolic activity or by decomposition of organic material, which is more abundant in mussel beds than in mussel ropes. Richard et al. (2006) concluded that the AFOM complex on mussel ropes, and specifically the decomposition of organic material, contributes most to nitrate, nitrite and silicate fluxes. Prins \& Smaal (1990) also measured high nitrate, nitrite and silicate release rates in mussel beds. Low nitrate and nitrite fluxes were observed in our study $(<10 \%$ of total DIN flux), but these rates were comparable to those of Richard et al. (2006). Those rates are considerably lower than nitrate and nitrite rates measured on mussel beds $(>20 \%$ of total dissolved inorganic nitrogen [DIN] flux, Prins \& Smaal 1990). No major anoxic areas were observed within our ropes (H. M. Jansen unpubl. data) and nitrate and nitrite were therefore unlikely to have been directly removed by denitrification. Rather, less organic material was present on the ropes compared to the mussel beds. Absence of silicate release by bivalve cultures as observed in our study is in disagreement with Richard et al. $(2006,2007)$ and Prins \& Smaal (1990). Silicate uptake in March can be attributed to uptake by diatoms, which were abundantly present during the spring bloom (H. M. Jansen unpubl. data). Silicate release could originate from the dissolution and microbial degradation of siliceous diatom tests (Canfield et al. 2005) that could be trapped in mussel biodeposits (Callier et al. 2009). However, as silicate concentrations were low during large periods of the year (Fig. 2B) and diatoms were only present during the spring and autumn bloom (data from http://alge- info.imr.no), few diatom tests might have been present in the mussel biodeposits during large periods of the year, which may explain the lack of silicate fluxes measured along the mussel rope interface.

\section{Interactions between suspended mussel culture and its environment}

The ecological importance of nutrient regeneration is enhanced nutrient availability for phytoplankton, resulting in increased primary production rates (Smaal 1991). Average nutrient ratios for phytoplankton growth are 16:16:1 for Si:N:P (Redfield et al. 1963), and deviations from this ratio in combination with low absolute nutrient concentrations may result in nutrient limitation for phytoplankton growth (Goldman et al. 1979). Subsequently, changes of nutrient ratios in the water column can lead to a shift in phytoplankton community composition (Dame \& Libes 1993, Prins et al. 1995). This study showed low ambient nutrient concentrations in spring and summer and N:P ratios $<16$ and $\mathrm{N}: \mathrm{Si}$ ratios $<1$ during extended periods of the year (Figs. 2B \& Fig. 5). These results point towards a nitrogen limited system, which is commonly observed in marine environments (Nixon et al. 1996). Mussel ropes release inorganic nitrogen and phosphorus into the water column (Fig. 4) and may thereby favour phytoplankton growth. However, net release was not according to Redfield's ratio, as proportionally more nitrogen was produced than phosphorus and silicate $(\mathrm{N}>\mathrm{P}>\mathrm{Si}$ ). During part of the nutrient-limited period (May to July), N:P flux ratios did not exceed Redfield's ratio of 16 (Fig. 5), which indicates that although mussel cultures release more nitrogen than phosphorus, they do not eliminate nitrogen limitation. However, the absence of silicate release by mussel ropes might lead to silicate rather than nitrogen limitation. Mussel cul-

Table 3. Average, maximum and minimum nitrogen and phosphate releases by a suspended mussel farm in relation to background fluxes in the dissolved nutrient pools (ambient water)

\begin{tabular}{|lccc|}
\hline & $\begin{array}{c}\text { Mussel } \\
\text { farm } \\
\left(\mathrm{kg} \mathrm{d}^{-1}\right)\end{array}$ & $\begin{array}{c}\text { Ambient } \\
\text { water } \\
\left(\mathrm{kg} \mathrm{d}^{-1}\right)\end{array}$ & $\begin{array}{c}\text { Mussel farm } \\
\text { vs. ambient } \\
\text { nutrient flux (\%) }\end{array}$ \\
\hline Nitrogen & & & \\
Average & 1.4 & 72.8 & 2.0 \\
Max. (Aug) & 2.4 & 12.8 & 18.9 \\
Min. (Feb) & 0.2 & 211.8 & 0.1 \\
Phosphate & & & \\
Average & 0.2 & 16.6 & 1.4 \\
Max. (Aug) & 0.3 & 6.5 & 4.6 \\
Min. (Feb) & 0.01 & 41.4 & 0.0 \\
\hline
\end{tabular}


tures thereby have the potential to suppress the development of siliceous phytoplankton such as diatoms (Turner et al. 1998) and favour the development of non-siliceous phytoplankton such as flagellates and dinoflagellates. Phytoplankton composition is not solely dependent on nutrient ratios but absolute nutrient concentrations may also play a role. Silicate concentrations have been shown to affect the phytoplankton community structure (Egge \& Aksnes 1992, Fouillaron et al. 2007), and diatom-dominated systems are stimulated if silicate concentrations exceeded $2 \mu \mathrm{M}$ (Egge \& Aksnes 1992). Effects of silicate limitation would therefore be more profound in summer periods when silicate concentrations are $<2 \mu \mathrm{M}$.

Nutrient release rates of mussel ropes measured in the present study may be extrapolated to farm-scale levels to evaluate the impact of mussel farming on inorganic nutrient pools. Combining ambient nutrient concentrations (Fig. 2B) and flux estimates (Fig. 4) with farm characteristics (length and width of farm, current velocities, length of longlines) as described in Strohmeier et al. (2008) allows us to estimate the amount of nutrients excreted by a mussel farm relative to the amount of nutrients naturally present in the water column (Table 3). The number of longlines (mussel biomass) provided by Strohmeier et al. (2008) were standardized to a regular mussel farm, which has $\sim 5$ times fewer longlines. In winter (February) when release by mussel cultures is low and ambient nutrient concentrations are high, the impact of mussel farming on the total nutrient pool is insignificant. On the other hand, in summer (August) mussel farming can increase the amount of DIN by $20 \%$ and the amount of dissolved inorganic phosphorus by $5 \%$. As fjord systems in Norway are nutrient limited (Paasche \& Erga 1988, Erga 1989a,b, Sæetre 2007), it can be postulated that enhanced nutrient availability stimulates primary production. The farm-scale estimates above are restricted to a single mussel farm, but while evaluating the effects of nutrient regeneration on fjord ecosystem level, dilution and dispersion processes should be taken into account.

In conclusion, this study has shown (1) an increase in species richness and biomass of fauna associated with mussel cultures through time, (2) a stable amount of organic material associated with mussel ropes through time, (3) a dominating role of mussels in nutrient releases in comparison to the AFOM complex, (4) seasonal fluctuations in nutrient release rates by mussel ropes, (5) a dissimilar release of different elements $(\mathrm{N}$ $>\mathrm{P}>\mathrm{Si}$ ), and (6) a substantial effect of mussel cultures on nutrient regeneration, especially in summer when the pool of naturally available nutrients is low and release rates by mussel cultures are high. The temporal fluctuations involved in these processes are relevant in management advice.
Acknowledgements. The authors thank Åfjord Skjell AS for providing the mussel ropes. We thank P. Cranford for providing advice on the development of the pelagic chambers. We also thank L. Lunde-Fonnes and J. Møgster-Strømstad for their contributions in the laboratory and T. Kutti has been of great value in the determination of the associated fauna. We thank M. Richard, R. Bannister and 3 anonymous reviewers for their constructive comments on the manuscript. This project was carried out as part of the PhD study of the principal author, within the institute program Carrying Capacity in Norwegian Aquaculture (CANO - Research Council of Norway, project no. 173537) at the Institute of Marine Research in Bergen, Norway.

\section{LITERATURE CITED}

Aksnes DL, Aure J, Kaartvedt S, Magnesen T, Richard J (1989) Significance of advection for the carrying capacities of fjord populations. Mar Ecol Prog Ser 50:263-274

Arakawa KY (1990) Competitors and fouling organisms in the hanging culture of the Pacific oyster, Crassostrea gigas (Thunberg). Mar Freshw Behav Physiol 17:67-94

Asmus RM, Asmus H (1991) Mussel beds: limiting or promoting phytoplankton? J Exp Mar Biol Ecol 148:215-232

Asplin L, Salvanes AGV, Kristoffersen JB (1999) Nonlocal wind-driven fjord-coast advection and its potential effect on plankton and fish recruitment. Fish Oceanogr 8: 255-263

Aure J, Danielssen D, Sætre R (1996) Assessment of eutrophication in Skagerrak coastal waters using oxygen consumption in fjordic basins. ICES J Mar Sci 53:589-595

Aure J, Strand O, Erga SR, Strohmeier T (2007a) Primary production enhancement by artificial upwelling in a western Norwegian fjord. Mar Ecol Prog Ser 352:39-52

Aure J, Strohmeier T, Strand O (2007b) Modelling current speed and carrying capacity in long-line blue mussel (Mytilus edulis) farms. Aquacult Res 38:304-312

> Baudinet D, Alliot E, Berland B, Grenz C, Plantecuny MR, Plante R, Salenpicard C (1990) Incidence of mussel culture on biogeochemical fluxes at the sediment-water interface. Hydrobiologia 207:187-196

Bayne BL, Hawkins AJS, Navarro E, Iglesias IP (1989) Effects of seston concentration on feeding, digestion and growth in the mussel Mytilus edulis. Mar Ecol Prog Ser 55:47-54

Bayne BL, Iglesias JIP, Hawkins AJS, Navarro E, Heral M, Deslouspaoli JM (1993) Feeding behaviour of the mussel, Mytilus edulis: responses to variations in quantity and organic content of the seston. J Mar Biol Assoc UK 73: 813-829

Brigolin D, Dal Maschio G, Rampazzo F, Giani M, Pastres R (2009) An individual-based population dynamic model for estimating biomass yield and nutrient fluxes through an off-shore mussel (Mytilus galloprovincialis) farm. Estuar Coast Shelf Sci 82:365-376

Callier MD, Weise AM, McKindsey CW, Desrosiers G (2006) Sedimentation rates in a suspended mussel farm (GreatEntry Lagoon, Canada): biodeposit production and dispersion. Mar Ecol Prog Ser 322:129-141

Callier MD, Richard M, McKindsey CW, Archambault P, Desrosiers G (2009) Responses of benthic macrofauna and biogeochemical fluxes to various levels of mussel biodeposition: an in situ 'benthocosm' experiment. Mar Pollut Bull 58:1544-1553

Canfield DE, Kristensen E, Thamdrup B (2005) Aquatic geomicrobiology. Advances in marine biology, Vol 48. Elsevier Academic Press, London 
Cayer D, MacNeil M, Bagnall AG (1999) Tunicate fouling in Nova Scotia aquaculture: a new development. J Shellfish Res 18: 327

Cranford PJ, Strain PM, Dowd M, Hargrave BT, Grant J, Archambault MC (2007) Influence of mussel aquaculture on nitrogen dynamics in a nutrient enriched coastal embayment. Mar Ecol Prog Ser 347:61-78

Dame R, Libes S (1993) Oyster reefs and nutrient retention in tidal creeks. J Exp Mar Biol Ecol 171:251-258

Dowd M (2005) A bio-physical coastal ecosystem model for assessing environmental effects of marine bivalve aquaculture. Ecol Model 183:323-346

Duinker A, Haland L, Hovgaard P, Mortensen S (2008) Gonad development and spawning in one and two year old mussels (Mytilus edulis) from Western Norway. J Mar Biol Assoc UK 88:1465-1473

Egge JK, Aksnes DL (1992) Silicate as regulating nutrient in phytoplankton competition. Mar Ecol Prog Ser 83:281-289

Ehrhardt M (1983) Determination of particulate organic carbon and nitrogen. In: Grasshoff K, Kremling K, Ehrhardt $\mathrm{M}$ (eds) Methods of seawater analysis. Verlag Chemie, Weinheim, p 269-275

Erga SR (1989a) Ecological studies on the phytoplankton of Boknafjorden, western Norway. II. Environmental control of photosynthesis. J Plankton Res 11:785-812

Erga SR (1989b) The importance of external physical controls on vertical distribution of phytoplankton and primary production in fjords of western Norway. PhD dissertation, University of Bergen

Erga SR, Aursland K, Frette O, Hamre B and others (2005) UV transmission in Norwegian marine waters: controlling factors and possible effects on primary production and vertical distribution of phytoplankton. Mar Ecol Prog Ser 305:79-100

Field A (2005) Discovering statistics using SPSS. Sage Publications, London

> Fouillaron P, Claquin P, L'Helguen S, Huonnic P and others (2007) Response of a phytoplankton community to increased nutrient inputs: a mesocosm experiment in the Bay of Brest (France). J Exp Mar Biol Ecol 351:188-198

Giles H, Pilditch CA, Bell DG (2006) Sedimentation from mussel (Perna canaliculus) culture in the Firth of Thames, New Zealand: impacts on sediment oxygen and nutrient fluxes. Aquaculture 261:125-140

Giles H, Broekhuizen N, Bryan KR, Pilditch CA (2009) Modelling the dispersal of biodeposits from mussel farms: the importance of simulating biodeposit erosion and decay. Aquaculture 291:168-178

Goldman JC, McCarthy JJ, Peavey DG (1979) Growth rate influence on the chemical composition of phytoplankton in oceanic waters. Nature 279:210-215

Goodbody I (1974) Physiology of ascidians. Adv Mar Biol 12: $1-149$

Grant J (1996) The relationship of bioenergetics and the environment to the field growth of cultured bivalves. J Exp Mar Biol Ecol 200:239-256

Grant J, Cranford P, Hargrave B, Carreau M and others (2005) A model of aquaculture biodeposition for multiple estuaries and field validation at blue mussel (Mytilus edulis) culture sites in eastern Canada. Can J Fish Aquat Sci 62: $1271-1285$

Grassle JF, Grassle JP (1974) Opportunistic life histories and genetic systems in marine benthic polychaetes. J Mar Res 32:253-284

Hatcher A, Grant J, Schofield B (1994) Effects of suspended mussel culture (Mytilus spp.) on sedimentation, benthic respiration and sediment nutrient dynamics in a coastal bay. Mar Ecol Prog Ser 115:219-235

Holmes RM, Aminot A, Kerouel R, Hooker BA, Peterson BJ (1999) A simple and precise method for measuring ammonium in marine and freshwater ecosystems. Can J Fish Aquat Sci 56:1801-1808

Kerouel R, Aminot A (1997) Fluorometric determination of ammonia in sea and estuarine waters by direct segmented flow analysis. Mar Chem 57:265-275

Khalaman VV (2001) Fouling communities of mussel aquaculture installations in the White Sea. Russ J Mar Biol 27: 227-237

LeBlanc N, Davidson J, Tremblay R, McNiven M, Landry T (2007) The effect of anti-fouling treatments for the clubbed tunicate on the blue mussel, Mytilus edulis. Aquaculture 264:205-213

> Lutz-Collins V, Quijon P, Davidson J (2009) Blue mussel fouling communities: polychaete composition in relation to mussel stocking density and seasonality of mussel deployment and sampling. Aquacult Res 40:1789-1792

- Mazouni N (2004) Influence of suspended oyster cultures on nitrogen regeneration in a coastal lagoon (Thau, France). Mar Ecol Prog Ser 276:103-113

Mazouni N, Gaertner JC, Deslous-Paoli JM (2001) Composition of biofouling communities on suspended oyster cultures: an in situ study of their interactions with the water column. Mar Ecol Prog Ser 214:93-102

> McKindsey CW, Lecuona M, Huot M, Weise AM (2009) Biodeposit production and benthic loading by farmed mussels and associated tunicate epifauna in Prince Edward Island. Aquaculture 295:44-51

Newell RIE (2004) Ecosystem influences of natural and cultivated populations of suspension-feeding bivalve molluscs: a review. J Shellfish Res 23:51-61

Nixon SW (1995) Coastal marine eutrophication: a definition, social causes, and future concerns. Ophelia 41:199-219

> Nixon SW, Ammerman JW, Atkinson LP, Berounsky VM and others (1996) The fate of nitrogen and phosphorus at the land-sea margin of the North Atlantic Ocean. Biogeochemistry 35:141-180

Paasche E, Erga SR (1988) Phosphorus and nitrogen limitation of phytoplankton in the inner Oslofjord (Norway). Sarsia 73:229-243

Parsons TR, Maita Y, Lalli CM (1992) A manual of chemical and biological methods for seawater analysis. Pergamon Press, New York, NY

Pearson TH, Rosenberg R (1978) Macrobenthic succession in relation to organic enrichment and pollution of the marine environment. Oceanogr Mar Biol Annu Rev 16:229-311

Petersen JK (2007) Ascidian suspension feeding. J Exp Mar Biol Ecol 342:127-137

Prins TC, Smaal AC (1990) Benthic-pelagic coupling: the release of inorganic nutrients by an intertidal bed of Mytilus edulis. In: Barnes M, Gibson RN (eds) Trophic relationships in marine environments. Proc 24th Eur Mar Biol Symp. Aberdeen University Press, Aberdeen, p 89-103

Prins TC, Smaal AC (1994) The role of the blue mussel Mytilus edulis in the cycling of nutrients in the Oosterschelde estuary (The Netherlands). Hydrobiologia 282/283:413-429

Prins TC, Escaravage V, Smaal AC, Peeters JCH (1995) Nutrient cycling and phytoplankton dynamics in relation to mussel grazing in a mesocosm experiment. Ophelia 41: 289-315

Prins T, Smaal A, Dame R (1998) A review of the feedbacks between bivalve grazing and ecosystem processes. Aquat Ecol 31:349-359 
Quinn GP, Keough MJ (2002) Experimental design and data analysis for biologists. Cambridge University Press, Cambridge

Redfield AC, Ketchum BH, Richards FA (1963) The influence of organisms on the composition of sea-water. In: Hill NM (ed) The sea, Vol 2. Wiley-Interscience, New York, NY, p 26-77

Richard M, Archambault P, Thouzeau G, Desrosiers G (2006) Influence of suspended mussel lines on the biogeochemical fluxes in adjacent water in the Îles-de-la-Madeleine (Quebec, Canada). Can J Fish Aquat Sci 63:1198-1213

Richard M, Archambault P, Thouzeau G, McKindsey CW, Desrosiers G (2007) Influence of suspended scallop cages and mussel lines on pelagic and benthic biogeochemical fluxes in Havre-aux-Maisons Lagoon, Îles-de-laMadeleine (Quebec, Canada). Can J Fish Aquat Sci 64: 1491-1505

Sætre R (ed) (2007) The Norwegian coastal currentoceanography and climate. Tapir Academic Press, Trondheim

Smaal AC (1991) The ecology and cultivation of mussels: new advances. Aquaculture 94:245-261

Smaal AC, Vonck A, Bakker M (1997) Seasonal variation in physiological energetics of Mytilus edulis and Cerastoderma edule of different size classes. J Mar Biol Assoc UK 77:817-838

Strickland JDH, Parsons TR (1968) A practical handbook of seawater analysis, Vol 167. Fisheries Research Board of Canada Bulletin, Ottawa

Strohmeier T (2009) Feeding behaviour and bioenergetic balance of the great scallop (Pecten maximus) and the blue mussel (Mytilus edulis) in a low seston environment and relevance to suspended shellfish aquaculture.

Editorial responsibility: Jana Davis, Annapolis, Maryland, USA
$\mathrm{PhD}$ dissertation, University of Bergen, Bergen (https://bora.uib.no/bitstream/1956/3713/1/Dr.thesis_Tore $\%$ 20Strohmeier.pdf)

Strohmeier T, Duinker A, Strand O, Aure J (2008) Temporal and spatial variation in food availability and meat ratio in a longline mussel farm (Mytilus edulis). Aquaculture 276: 83-90

Strohmeier T, Strand O, Cranford P (2009) Clearance rates of the great scallop (Pecten maximus) and blue mussel (Mytilus edulis) at low natural seston concentrations. Mar Biol 156:1781-1795

Taylor JJ, Southgate PC, Rose RA (1997) Fouling animals and their effect on the growth of silver-lip pearl oysters, Pinctada maxima (Jameson) in suspended culture. Aquaculture 153:31-40

Turner RE, Qureshi N, Rabalais NN, Dortch Q, Justic D, Shaw RF, Cope J (1998) Fluctuating silicate:nitrate ratios and coastal plankton food webs. Proc Natl Acad Sci USA 95: 13048-13051

- Vooys CGN (1976) The influence of temperature and time of year on the oxygen uptake of the sea mussel Mytilus edulis. Mar Biol 36:25-30

Wassmann P (1990) Relationship between primary and export production in the boreal coastal zone of the North Atlantic. Limnol Oceanogr 35:464-471

Weise AM, Cromey CJ, Callier MD, Archambault P, Chamberlain J, McKindsey CW (2009) Shellfish-DEPOMOD: Modelling the biodeposition from suspended shellfish aquaculture and assessing benthic effects. Aquaculture 288:239-253

Widdows J, Bayne BL (1971) Temperature acclimation of Mytilus edulis with reference to its energy budget. J Mar Biol Assoc UK 51:827-843

Submitted: December 6, 2010; Accepted: February 19, 2011

Proofs received from author(s): May 19, 2011 